Volume 2

Number 2 Teaching Secrecy

January 2021

\title{
Giants: The Global Power Elite
}

Susan Maret

San Jose State University, drsmaret@gmail.com

Follow this and additional works at: https://scholarworks.sjsu.edu/secrecyandsociety

Part of the Civic and Community Engagement Commons, Other Sociology Commons, Politics and Social Change Commons, and the Public Affairs, Public Policy and Public Administration Commons

\section{Recommended Citation}

Maret, Susan. 2021. "Giants: The Global Power Elite." Secrecy and Society 2(2). https://doi.org/10.31979/2377-6188.2021.020213 https://scholarworks.sjsu.edu/ secrecyandsociety/vol2/iss2/13

This Book Review is brought to you for free and open access by the School of Information at SJSU ScholarWorks. It has been accepted for inclusion in Secrecy and Society by an authorized administrator of SJSU ScholarWorks. For more information, please contact scholarworks@sjsu.edu.

\section{(c) (1)}

This work is licensed under a Creative Commons Attribution 4.0 License. 


\section{Giants: The Global Power Elite}

\section{Keywords}

human rights, C. Wright Mills, openness, power elite, secrecy, transnational corporations, transparency 
Review, Giants: The Global Power Elite by Peter Philips

Reviewed by Susan Maret

Giants: The Global Power Elite, New York: Seven Stories Press, 2018. 384pp. / ISBN: 9781609808716 (paperback) / ISBN: 9781609808723 (ebook) https://www.sevenstories.com/books/4097-giants

The strength of Giants: The Global Power Elite lies in its heavy documentation of the "globalized power elite, [a] concept of the Transnationalist Capitalist Class (TCC), theorized in the academic literature for some twenty years" (Phillips 2018, 9). Through the use of power structure theory, Giants' illustrates a confederation that represents the new normalcy in terms of how things get done on a global level, often below the radar of public awareness. This confederation has influence over resources (e.g., information, knowledge), communication (e.g., press, the media, Internet), trade, banking, economies, the environment, and in certain cases, governments. This often invisible network has tremendous implications for democracy and human rights, certainly in terms of participatory governance and the right to know. Peter Philips, professor of political sociology at Sonoma State University, former director of Project Censored and president of the Media Freedom Foundation from 2003 to 2017, is uniquely poised to make this interconnected power grid visible and has done so in Giants. ${ }^{1}$

Below, I discuss Giants' theoretical framework and its contents, also noting

1 Philips' academic biography is found at: https://web.sonoma.edu/sociology/faculty/peterphillips.html; Philips wrote his dissertation on the San Francisco Bohemian Club and research areas are political sociology and sociology of media and teaches He teaches courses at Sonoma State University in Political Sociology, Sociology of Power, Sociological of Media, Sociology of Conspiracies and Investigative Sociology. 
the book's contribution and shortcomings.

\section{The Sociological Orientation of Giants: Power Structure Research}

The Global Power Elite as defined by Philips (2018) "function(s) as a nongovernmental network of similarly educated wealthy people with common interests of managing, facilitating, and protecting concentrated global wealth and insuring continued growth of capital" (9). To study this network of elites, Phillips employs power structure theory and research, which takes apart the interrelations of influence. Power structure research, as I understand this framework, allows us to ask questions: are global power networks corrosive tools of privileged individuals and groups, or necessary adjuncts to finance, trade, and diplomacy? If we think Foucauldian, perhaps these networks have characteristics of both, but nevertheless must be forensically examined as to their power relations. Here G. William Domhoff (2007) weighs in:

So, what is power structure research, exactly? It is first of all an attempt to construct the networks of people and institutions that run the show, although it must immediately be added that the overall theory concerns more than the top levels of society. Power relations run from top to bottom, like a pecking order, only more complicated. The social structure is not simply an organized elite or class at the top, with an unorganized mass or united working class below it. There are many power niches and potential bases for exercising power below the top.. (2)

In the preface to Giants, Phillips (2018) points out that his book "follows in the tradition of C. Wright Mills's 1956 The Power Elite" (9). Power structure research, as Domhoff (2007b) observes, also originated with Floyd Hunter's (1952) study of community power in Atlanta; Domhoff (2007b) writes that Hunter and Mills 
are relatively distinctive in that they see power as originally rooted in organizations, not in individuals, voluntary associations, interest groups, and parties, as mainstream political science does, nor in classes, as Marxists do, although they certainly agree that voluntary associations, interest groups, and classes can arise historically in some countries from their organizational base, as has been the case in industrialized capitalist societies. On the other hand, Mills, Hunter, and the field of research they created do not see organizations in the neutral and benign way. (97) ${ }^{2}$

Here I pose that while Hunter and Mills certainly opened the proverbial door to show us how groups with mutual interests act and react, Giants also follows in the tradition of those texts (or genre) that provide the basis for investigations of the intermeshed national/transnationalist global structure (Chomsky 2016; Domhoff 1978, 1990, 2014, 20183; Gil 1991; Knudsen 2016; Mann 2013; Prewitt and Stone 1973; Richardson, Kakabadse, and Kakabadse 2011; Sklar 1980, 1986; Sutton 1978), 4 "superclass" (Rothkopf 2009; Phillips 2018, 27), and "plutocrats" (Freeland 2012). Of particular significance to Giants is also Michael Mann's (1986) theory of four "overlapping and intersecting sociospatial networks of power" that consists of the ideological, economic, military, and political (1).

\section{The Book}

In its chapters, Philips (2018) identifies and expands on the members of the Global Power Elite, who "are key stewards of a major part of the world's financial wealth" (303). This wealth is being "used for economic colonization and privatization of the public commons in complete disregard for human rights" (Phillips 2018, 303). Below, I sketch each chapter in Giants alongside the

2 Also see Domhoff (2007a).

3 And various iterations of the influential Who Rules America published from 1967-2014.

4 See Robinson 2005 and Schiller, Basch, and Blanc-Szanton (1992) as a foundation. 
strengths of the book:

Introduction, Who Rules the World is written by sociologist William I.

Robinson, who is no stranger to documenting the "power networks" that

constitute the basis of global capitalism, TCCs, and transnationalism in his own

research. ${ }^{5}$ In the introduction, Robinson (2018) writes of Giants that

...Professor Phillips exposes an inner core of 389 individuals drawn from the upper echelons of the transnational capitalist class who stand at the very apex of this global power structure. An earlier generation of power elite studies focused on the corporate and political networks that rule at the national level. But this earlier generation of studies has become outdated in the wake of capitalist globalization. What were national capitalist classes have developed through the transnational integration of their capitals into a transnational capitalist class. (17)

Chapter 1, Transnational Capitalist Class Power Elite: A Seventy Year History traces "the transition from the nation state power elites described by [C.Wright] Mills to a transnational power elite centralized on the control of global capital around the world" (Phillips 2018, 9).${ }^{6}$ Among the history that Phillips includes is an examination of Mills' higher-circle policy elites and a review of the literature on the TCC.

Chapter 2, The Global Financial Giants: The Central Core of Global Capitalism consists of seventeen [asset manager] firms that "not only invest in each other but in many hundreds" more (Phillips 2018, 11, 35). These firms range from BlackRock, Vanguard, J.P. Morgan Chase, to Morgan Stanley \& Co, and their investment connections and a subset of firms termed New Giants and Near

5 Robinson's faculty page at UC Santa Barbara for a list of publications: http://robinson.faculty.soc.ucsb.edu/

6 As in the Forbes 400, Definitive Ranking of the Wealthiest Americans, https://www.forbes.com/forbes-400/\#4041d667e2ff 
Giants (Phillips 2018, 48, 49). As of early 2017, these seventeen firms have more than one trillion dollars in assets and symbiotically "invest in each other." Phillips' heavy lifting here identifies those companies that "comprise the core of global capitalism, and thus who makes the financial decisions regarding the use of the world's wealth" (Phillips 2018, 37-38).

Chapter 3, Managers: The Global Power Elite of Financial Giants identifies the 199 directors of the top seventeen asset management firms outlined in chapter 2; this club of 199 "are the central power elite core of global financial capitalism" (Philips 2018, 148). As Phillips (2018) notes, "the specific names of the power elites running the financial centers of the world are rarely identified in the context of a world class structure" (61). Biographical and net wealth information on the 199 members illustrate common bonds, insularity, and power relations through their affiliations with the World Economic Forum, WTO, Federal Reserve Board, G7, G20, IMF, universities, policy groups, social clubs and "cultural enterprises" (Philips 2018, 11).

Chapter 4, Facilitators: The Power Elite Policy Planning Center of the Transnational Capitalist Class is a discussion of interlocking policy groups that "serve as institutionalized mechanisms for TCC consensus building, and power elite formation and implementation" (Phillips 2018, 161). Among facilitators identified by Phillips, some IGOs (intergovernmental organizations), are the World Bank, IMF, G30, G20, G7, WTO, World Economic Forum, Trilateral Commission, Bilderburg Group, Aspen Institute, Council on Foreign Relations (CFR), and Bank for International Settlements. As Phillip (2018) observes, these "facilitators" act 
to "unite the TCC power elites as a class" (162).

Chapter 5: Protectors: The Power Elite and the US Military, NATO Empire, Intelligence Agencies, and Private Military Companies examines those entities that guard "concentrated global capital," or that wealth, which "requires a system of laws and police power to protect itself" (Phillips 2018, 12). Among protectors reported by Phillips are NATO, branches of the US military, weapons manufacturers (e.g., Lockheed Martin), private military companies, intelligence agencies, and NGOs such as the Atlantic Council. One important aspect of this chapter is the inclusion of biographies.

Chapter 6: Ideologists: Corporate Media and Public Relations Propaganda Firms examines the corporate media and the "expanding use of public relations propaganda companies in the news system of the world" (Phillips 2018, 13). The chapter includes a brief discussion of "symbiotic news distribution," public relations and marketing firms, telecommunications corporations, the "propaganda model of corporate media," and Chomsky and Herman's Propaganda Model (Phillips 2018, 265, 273-279). ${ }^{7}$ Companies such as Comcast, Disney, and Viacom/CBS, Omnicom Group, and WPP are discussed in terms of their influence on public opinion, entertainment, and manufacture of news.

Chapter 7: Facing the Juggernaut: Democracy Movements and Resistance acts as a summary of Giants and "what needs-to-be-done statement" (Phillips 2018, 13). The 1948 United Nations' Universal Declaration of Human Rights is cited in full "as a document that social movements can easily adopt as a guide for

7 The Sinclair Broadcast Group is not included. 
Maret: Giants: The Global Power Elite

corrective actions needed in the world today" (Phillips 2018, 307).

Postscript: Letter to the Global Power Elite is an appeal to the Global Power

Elite in terms of conscience and signed by noted academics, activists, and writers.

\section{Giants: Shortcomings}

First, Giants would benefit from a glossary that includes brief definitions of globalization, Mills' power elite and higher circles, transnationalism, the Transnationalist Capitalist Class, "transnationalist ruling elites," all terms that are often used interchangeably in the text, but perhaps have subtle differences.

Concepts such as ideology, discussed in Chapter 6 for example, is not expressly linked within the context of the work of Bernays nor Herman and Chomsky's corporate media and propaganda model. This lack of foundation leaves a knowledge gap for some readers, and for others, to approach the material within their own basis of understanding. On my end, I viewed Chapter 6 through the lens of Mannheim (1954), who writes that ideology

reflects the one discovery which emerged from political conflict, namely, that ruling groups can in their thinking become so intensively interestbound to a situation that they are simply no longer able to see certain facts which would undermine their sense of domination. There is implicit in the word "ideology" the insight that in certain situations the collective unconscious of certain groups obscures the real condition of society both to itself and to others and thereby stabilizes it. $(36)^{8}$

Framing ideology, then linking it to the propaganda model, would have made for a stronger illustration of perhaps how those "ideologists," including corporate

8 Of particular importance is the distinction made by Mannheim $(1954,49,50)$ in his Ideology and Utopia between particular (or personal interests) and total ("ideology of an age or of a concrete historico-social group, e.g. of a class, when we are concerned with the characteristics and composition of the total structure of the mind of this epoch or of this group") ideology, both of which have relevance to discussion of power elite interest on a global level. 
media, not only aid, but are strategically employed by the global elite power network.

Secondly, the index, which is a critical discovery tool, has inexcusable structural errors. Subjects are indexed under the article "The" instead of the subject; for instance, the Chertoff Group is not listed under the letter "C" where most readers would search, but "The Chertoff Group." This oversight is more of a reflection on the publisher than the author, but it is still important to note that a broken index is more than an inconvenience. At a basic level, faulty indexing misleads researchers as to content that is cited and discussed within the body of a text. In addition, there are missing subjects listed in the index, such as the Herman and Chomsky's Propaganda Model outlined on page 277. Herman and Chomsky are included in the index, but not in relation to their model.

Third, Giants doesn't deeply delve into TCCs and their role in the "knowledge shaping process" as it pertains to manufacturing solutions and influencing policies; the book would be made stronger by the inclusion of a short chapter on the nature of power/knowledge/discourse (Foucault 1980; Hardy and Phillips 2004) and TCCs/Global Power Elite networks. ${ }^{9}$ Such a discussion would have tied into the Universal Declaration on Human Rights' Article 19 to information access and transparency. To this end, it is important to note that "in the knowledge-shaping process, elites actively work to influence what is known about a particular subject in an effort to achieve their policy goals" (Bonds 2011,

9 Thanks to Hamilton Bean for this important cite. 
Maret: Giants: The Global Power Elite

431). ${ }^{10}$ Further, the "knowledge-shaping process involves four distinct exercises of power," which have elements of concealment and censorship that also include the creation and dissemination of information/knowledge in order to advance specific world views:

1) Information suppression, in which elites purposively act to suppress knowledge damaging to their interests;

2) Contesting knowledge, in which elites fund experts to attack and disqualify knowledge that poses a threat to their power base. Elites may also fund diversionary efforts attacking those who have produced or who uphold potentially "damaging" knowledge (Freudenburg, 2005a; Freudenburg and Alario, 2007);

3) Knowledge production, in which elites fund or otherwise promote the production of particular knowledges, either through peer-reviewed scientific research or governmentally administered through tests and analyses;

4) Knowledge administration, in which elites influence the selection of what information counts as knowledge and what information does not count.11; (Bonds, 2011, 431)

Lastly, Giants missed an opportunity by not including a brief discussion on the New World Economic Order and the historical search for a code of conduct for transnational corporations (e.g., Rahim 2019; Sagafi-Nejad, Dunning, and Perlmutter 2008), ${ }^{12}$ which somewhat resulted in the United Nations' Global Compact. The Compact includes ten voluntary principles that stress corporate responsibility in terms of respect for human rights, fair labor practices, the use of

10 Although he addresses the knowledge-shaping process as tied to environmental policy, science, and politics, Bonds' discussion could be useful in framing the Global Power Elite.

11 For examples of Trilateral Commission knowledge-shaping, see Crozier, Huntington, and Watanuki (1975) and Owen, Ōkita, and Brzezinski (1984).

12 The U.N Code of Conduct on Transnational Corporations specifically, that was not adopted, and criticized as anti-business and a failure of regulatory oversight and governance. See for example, Committee on Foreign Affairs, House of Representatives. 1987. Review of the U.N. Code of Conduct for Transnational Corporations. Hearings before the Subcommittee on Human Rights and International Organizations, 100-1, May 7. Washington, DC: Government Publishing Office. 
precaution in environmental policy, and anti-corruption initiatives. Mention of the Compact would have not only complemented the use of Universal Declaration on Human Rights as used discussed in Giants, but supported the call for challenging The Global Power Elite as "a necessary agenda for democracy movements" (Phillips 2018, 318). ${ }^{13}$

\section{Conclusion}

Shortcomings aside, Giants: The Global Power Elite is a significant reference work that should be recognized for its substantive documentation of global networks and the people who run them. The book's almost encyclopedic nature is a tool for open source intelligence investigations (OSINT) into the nature of the global power structure, especially as it relates to research on political corruption and secrecy. In this regard, Giants complements the International Consortium of Investigative Journalists' (ICIJ) many investigations on secret corporate tax havens and the Transnational Institute's (TNI) State of Power annual reports, both of which supplement and reinforce Phillips' remarkable reporting on the TCCs. ${ }^{14}$

Lastly, as one reads through Phillips' text, it is impossible not to reflect on what lies beneath; secrecy, then, as the intentional concealment of information is

13 The Ten Principles are derived from the Universal Declaration of Human Rights, International Labour Organization's Declaration on Fundamental Principles and Rights at Work, the Rio Declaration on Environment and Development, and the United Nations Convention Against Corruption (United Nations n.d.).

14 See ICIJ at https://www.icij.org/investigations/\#/investigations and TNI's 2019 report for example, which "examines through essays and infographics the varied dimensions and dynamics of financial power, and how popular movements might regain control over money and finance." 
one of the themes of Giants. Generally speaking, members of the Global Power Elite are not subject to freedom of information laws or universal transparency rules. Moreover, an international patchwork of disclosure laws makes it an almost impossibility to have a full grasp of how elite members and their networks secretly intersect on a global scale. ${ }^{15}$ In this way, I would go as far to say Giants is fundamentally an anti-secrecy endeavor; it is a casebook for potential FOIA (Freedom of Information Act) requests, anti-corruption research, and to map invisible networks. As a reference work, Giants belongs on the shelf of public and academic libraries as well as with those researchers concerned with unlocking the secrets of the global power network of elites to create a more transparent, just world.

\section{References}

Bonds, Eric. 2011. "The Knowledge-shaping Process: Elite Mobilization and Environmental Policy." Critical Sociology 37, no. 4: 429-446.

Chomsky, Noam. 2016. Who Rules the World? New York: Metropolitan Books, Henry Holt and Company.

Cobham, Alex, Petr Janský, and Markus Meinzer. 2018. "A Half-century of Resistance to Corporate Disclosure." Transnational Corporations 25, no. 3: 127.

Crozier, Michel J., Samuel P. Huntington, and Joji Watanuki. 1975. The Crisis of Democracy: Report on the Governability of Democracies to the Trilateral Commission. New York: New York University Press. https://archive.org/details/TheCrisisOfDemocracy-TrilateralCommission-1975

Domhoff, G. William. 2018. Studying the Power Elite: Fifty Years of Who Rules America? New York: Routledge. 
. 2014. "The Council on Foreign Relations and the Grand Area: Case Studies on the origins of the IMF and the Vietnam War." Class, Race and Corporate Power 2, no. 1: 1 .

. 2007a. "C. Wright Mills, Floyd Hunter, and 50 years of Power Structure Research." Michigan Sociological Review 21: 1-54.

. 2007b. "C. Wright Mills, Power Structure Research, and the Failures of Mainstream Political Science." New Political Science 29, no. 1: 97-114.

. 1990. The Power Elite and the State: How Policy is Made in America. Hawthorne, NY: Aldine De Gruyter.

. 1978. The Powers That Be: Processes of Ruling Class Domination in America. New York: Vintage Books.

Foucault, Michel. 1980. Power/Knowledge: Selected Interviews and Other Writings, 1972-1977. New York: Vintage.

Freeland, Christina. 2012. Plutocrats: The Rise of the New Global Super-Rich and the Fall of Everyone Else. New York: Penguin Press.

Freudenburg William R. (2005). "Privileged Access, Privileged Accounts: Toward a Socially Structured Theory of Resources and Discourses." Social Forces 84, no. 1: 89-114.

Freudenburg William R., and Margarita Alario. (2007). "Weapons of Mass Distraction: Magicianship, Misdirection, and the Dark side of Legitimation." Sociological Forum 22, no. 2: 146-173.

Gill, Stephen. 1991. American Hegemony and the Trilateral Commission. New York: Cambridge University Press.

Hardy, Cynthia, and Nelson Phillips. 2004. "Discourse and Power." In The Sage Handbook of Organizational Discourse, edited by David Grant, Cliff Oswick, Cynthia Hardy, Linda L. Putnam, and Nelson Phillips, 299-316. Thousand Oaks, CA. Sage.

Hunter, Floyd. 1952. Community Power Structure: A Study of Decision Makers. Chapel Hill: University of North Carolina.

Knudsen, Dino. 2016. The Trilateral Commission and Global Governance: Informal Elite Diplomacy, 1972-82. New York: Routledge.

Mann, Michael. 2013. The Sources of Social Power: Globalizations, 1945-2011. Vol. 4. New York: Cambridge University Press.

. 1986. The Sources of Social Power: A History of Power from the Beginning to A.D. 1760. Vol. 1. New York: Cambridge University Press.

Mannheim, Karl. 1954. Ideology and Utopia: An Introduction to the Sociology of Knowledge. New York: Harcourt, Brace \& Co.

https://archive.org/details/ideologyutopiain00mann

Mills, C. Wright. [1956] 2000. The Power Elite. New afterword by Alan Wolfe. 
New York: Oxford University Press. https://archive.org/details/c wright mills the power elite

Owen, David, Saburō Ōkita, and Zbigniew Brzezinski. 1984. Democracy Must Work: A Trilateral Agenda for the Decade: A Task Force Report to the Trilateral Commission. New York: New York University Press.

Prewitt, Kenneth, and Alan Stone. 1973. The Ruling Elites: Elite theory, Power, and American Democracy. New York: HarperCollins.

Rahim, Mia Mahmudur. 2019. "Quest for a Global Code of Conduct for TNCs - A Grim Tale." In Code of Conduct on Transnational Corporations, edited by Mia Mahmudur Rahim, 1-22. Cham: Springer.

Richardson, Ian, Andrew Kakabadse, and Nada Kakabadse. 2011. Bilderberg People: Elite Power and Consensus in World Affairs. New York: Routledge.

Risso, Linda. 2014. Propaganda and Intelligence in the Cold War: The NATO Information Service. New York: Routledge.

Robinson, William I. 2005. "Global Capitalism: The New Transnationalism and the Folly of Conventional Thinking." Science \& Society 69, no. 3: 316-328.

Rothkopf, David J. 2009. Superclass: The Global Power Elite and the World They Are Making. New York: Farrar, Straus and Giroux.

Sagafi-Nejad, Tagi, John H. Dunning, and Howard V. Perlmutter. 2008. The UN and Transnational Corporations: From Code of Conduct to Global Compact. United Nations Intellectual History Project. Bloomington: Indiana University Press.

Schiller, Nina Glick, Linda Basch, and Cristina Blanc-Szanton. 1992. "Towards a Definition of Transnationalism." Annals of the New York Academy of Sciences 645, no. 1: ix-xiv.

Simmel, Georg. 1906. "The Sociology of Secrecy and of Secret Societies." American Journal of Sociology 11, no. 4: 441-498.

Sklar, Holly. 1986. Reagan, Trilateralism, and the Neoliberals: Containment and Intervention in the 1980s. Boston: South End Press.

, ed. 1980. Trilateralism: The Trilateral Commission and Elite Planning for World Management. Boston: South End Press, 1980.

Sutton, Anthony. 1978. Trilaterals Over Washington. Scottsdale, AZ: August Corp.

Transnational Institute. 2019. State of Power: Finance. https://www.tni.org/en/stateofpower2019

United Nations. n.d. The Ten Principles of the UN Global Compact. https://www.unglobalcompact.org/what-is-gc/mission/principles 
Secrecy and Society, Vol. 2, No. 2 [2021], Art. 13

https://scholarworks.sjsu.edu/secrecyandsociety/vol2/iss2/13

DOI: 10.31979/2377-6188.2021.020213 